\title{
Fund Size and Performance of Unit Trust Funds in Kenya
}

\author{
Anderson Namu Nthimba, Ambrose Jagongo, Lucy Wamugo \\ Department of Finance and Accounting, School of Business, Kenyatta University, Nairobi, Kenya \\ Email address: \\ nthimbaan@yahoo.com (A. N. Nthimba), ambrose.jagongo@ku.ac.ke (A. Jagongo), lucy.wamugo@ku.ac.ke (L. wamugo)
}

\section{To cite this article:}

Anderson Namu Nthimba, Ambrose Jagongo, Lucy Wamugo. Fund Size and Performance of Unit Trust Funds in Kenya. Journal of Finance and Accounting. Vol. 9, No. 1, 2021, pp. 8-15. doi: 10.11648/j.jfa.20210901.12

Received: October 18, 2020; Accepted: November 7, 2020; Published: February 10, 2021

\begin{abstract}
When investors take part in any investment, the main objective is to increase their wealth. This is achieved when share prices increase. The performance of unit trusts in Kenya has however been poor compared to the counterparts in the rest of the world. The poor performance is a discouragement to individual and corporate investors in addition to affecting the realisation of financial stability according to the Kenya vision 2030. Empirical literature from developed and emerging markets posits that fund size explain the performance of unit trust funds. This study therefore investigated the effects of fund size on the performance of unit trust funds in Kenya. The study adopted an explanatory research design and positivism philosophy. The target population was 16 unit trust firms in Kenya as at the end of the year 2017. The study used a census approach. Secondary data was collected from the audited financial statement of respective unit trusts for the period 2005 to 2017 using a data collection schedule. The study established that fund size has significant positive effect on performance in all funds. The study concluded that increase in fund size increases performance. The study recommends that capital market authority should monitor performance of unit trusts constantly and in addition develop merger policies to encourage small unit trust to merge in order to take advantage of economies of scale.
\end{abstract}

Keywords: Fund Size, Unit Trust Funds, Performance, Unit Trust Funds Performance

\section{Introduction}

The investment canon put forward by Goetzmann posits the earning of returns as the reason for investments by any investor [16]. The desire for earnings in the future backs the motivation to invest and that the earning anticipated should be able to meet future cash needs [28]. Further, investors' motivation in investing anchors on the desire to increasing wealth and growing over time the initial investment. Investment returns compensate for the investment period, the inflation rate and the repayment uncertainty [37].

An investment in unit trusts funds is as common as investing in shares and is prevalent amongst stockholders universally since it grants them a chance to receive earnings [17]. Unit trusts offer investors a chance of earning yearly proceeds in the form of bonuses/dividends. It also serves as a basis for the long term and short term build-up of wealth resembling a savings account $[43,30]$. The objective of making investments in unit trust funds is earning dividend income or obtaining capital gains. Capital gains are realized when there is an increase in the price of a unit trust fund, or returns of a unit trust fund are positive during the holding period [17].

Empirical literature on performance of unit trust funds in developing, emerging and developed capital markets presents mixed results. Some reported underperformance while others reported over performance. Bonolo, Beatrice and John; Praven, Das and Uma; and William reported weak performance or underperformance [50, 49], 44]. Mohamed; Halil; and See and Jusoh reported positive performance or outperformance of unit trust funds [30, 20, 41].

For enhanced decisions, investors should be well versed with individual unit trusts fund share returns as well as the fund characteristics that influence returns in unit trust funds [51]. This study examined the effect of fund size on the performance of unit trust funds in Kenya.

\subsection{Fund Size}

Fund size plays an essential part in clarifying variances across unit trust funds performance [15]. This study investigated the effect of fund size on the performance of unit trust funds, which is among the most common and significant variables amongst the literature. Investors inject more money 
to better performing funds and withdraw or avoid injecting more funds to poorly performing funds [4]. Fund size is calculated as the Net Asset Value (NAV) for each unit trust fund based on the method of measurement by Carhart [9].

Brennan and Hughes argued that, large funds present a wide spread for fixed expenses, more resources for research, better opportunities of investment that are not available to smaller funds in addition to negotiating improved ranges due to more prominent positions and trading capacities [5]. However, large funds experience particular difficulties in administration and persistence performance [2]. Funds with massive amounts experience deteriorating performance since investment avenues diminish [2]. Yin-Ching and Hung (2003) held a position that small funds outdo in performance their corresponding in the category of bond fund. Smaller funds focus on a small number of investment options, but when they become large, administrators need to continue finding better opportunities for investment; in effect, diseconomies of scale end up diluting the managerial skills [2].

Empirical studies across the various markets in the world do not agree on the effect of fund size on the performance of unit trust funds. Chen, Hong, Huang and Kubick argued of shrinking of returns with respect to scale for funds invested in the USA and a contrary position for funds located outside the USA [10]. Cremers and Petajisto showed smaller funds to be more active [11]. Grinblatt and Titman held evidence of a mixed relationship between fund size and fund returns [19]. Besides, once a fund obtains inflows, there is a tendency of increasing its positions as opposed to diversification into newer assets [36].

Yan; Edelen, Evans, and Kadlec pointed out the primary sources of diseconomies of scale in USA funds to be costs of trading and liquefication $[47,13]$. Compared to smaller equity funds, more substantial equity funds are inclined to performing more poorly outside the USA [12]. Generally, size-performance evidence isn't undivided. Current studies appear to be in support of the presence of diseconomies of scale. The reviews are, to a great extent obtained from developed markets, and it is paramount to make findings of fund size-performance effect in emerging markets as well as Kenya in particular. The size of unit trust industry has been increasing in the world across. In 2012, the total net assets in the sector amounted to United States Dollar (USD) 32 trillion and by 2017 had grown to USD 49 trillion with the USA and Europe, contributing the highest share [22]. In Kenya, the net asset value of the industry grew over the period to USD 558 million in 2017[8].

\subsection{Performance of Unit Trust Funds}

Typically, investors select funds based on partial performance, although sensitivity may be due to variances of past performance. Many studies suggest that conventional investors react by directing more cash to better performing funds and not the same way to inadequately performing funds [4]. Performance in the market solely determines the survival of the fund, that is, a persistent increase in capital gains for growth funds and constant returns for value funds. [15]. Maina asserts evaluation of unit trust funds performance in terms of capital growth, periodical returns in the form of dividends, interest received, capital gains and Net Asset Value [26].

In Kenya, like other countries, many investors are dependent on unit trust funds as vehicles of investment [26]. The unit trust market is greatly unexploited in Kenya and research on their performance is significantly deficient [15]. Assortment measures of performance have been used all through the literature to assess the performance of the funds. The commonly used measures are; Jensen Alpha, Treynor ratio and Sharpe ratio, [52]; [30]; [39]. Non-risk-adjusted measures such as fund return formulas, portfolio return formulas and Lower Partial Moment Capital Asset Pricing Model have also been used [30]; [39]. This study measured the performance of unit trust funds using Jensen Alpha. The ratio is the most used across literature in assessing riskadjusted returns of unit trusts funds.

Examination on some of the unit trust funds, show a trend of deteriorating performance. For example, Old Mutual equity fund generated a loss in 2015 and 2016 of Kenya shillings (Kshs) 74,982,000 and 227,225,000, respectively. Equity fund had a decrease in profits in the year 2016 of 16.3 per cent from the previous year 2015. The balanced fund had a loss of Kshs 27,552,000 in 2015. East African fund had losses dipping further in 2016. The Britam, equity fund had deteriorating profits from 2013 culminating into losses of Kshs 140,288,000 and 386,942,000 in the years 2016 and 2015 respectively. Cooperative insurance company funds, among others, exhibit a similar trend which indicates a gap for investigation.

\subsection{Unit Trust Funds in Kenya}

Unit trust funds are a set of financial securities carefully chosen to meet the specified group of potential investors' objectives [52]. The potential investors, in addition to lacking enough financial resources to construct a portfolio they also lack expertise, knowledge and time necessary in managing the portfolio [30]. Participants are shareholders who take up equity securities of the unit trust [45]. Unit trusts accord investors opportunities of investing in a well-diversified portfolio without them assuming the risk of managing the portfolio [3].

In developed markets, for example, United States of America (USA), the growth of mutual fund has been noteworthy over the past several years with the global Gross Domestic Product (GDP) growing to 36 per cent by the year 2014 [22]. Plantier asserts that the USA market established total cumulative capital inflows of approximately USD 10 trillion over the period $2000-2014$ [35]. The largest mutual fund industry in the world with over USD17.8 trillion in assets and accounting for more than half of the $\$ 33.4$ trillion of assets value is USA [21, 14]

Africa, when combined with Asia pacific, accounts for 13 percent of total world assets and is among the lowest in the world [21]. The unit trust industry in Kenya accounts for 0.80 per cent of Kenyans GDP [46] and USD 558 million [8]. Since its inception, there are a total of 20 unit trusts firms registered [8]. Central to the stock market performance of any country is the listed firms' financial performance in the economy at large [25]. Nairobi Securities Exchange (NSE) listed firms performance has been meager [32]. Makori posits 
that, some of the listed firms at the NSE are not only in unhealthy financial position but in addition, they have suffered financial decline and Capital Markets Authority (CMA) has delisted them. The fall, in return, affects the performance of unit trusts funds since NSE provides an investment platform for unit trust funds [27].

According to the Republic of Kenya, the vision 2030 financial services aims to raise savings and investment rates from 17 per cent to 30 per cent of Kenya's GDP and raise stock market capitalization from 50 per cent to 90 per cent of GDP [38]. However, nine years later, the unit trust industry contributes 0.80 per cent of the Kenyans GDP [46]. The unit trusts market in Kenya is mainly dominated by four core funds which include; money market, equity, bond and balanced funds [8].

\subsection{Statement of the Problem}

The unit trust markets in many countries are driving their economies in an upward trajectory. The Kenyan unit trust market on the other hand has continued to experience the poor performance with some reporting a stream of losses from year to year. Weak performance trends of unit trusts in Kenya are a discouragement to individual and corporate investors in addition to hindering the realization of vision 2030. Kenya's unit trust industry contributes an equivalent of 0.80 per cent of the country's GDP [46].

Countries that started unit trusts the same time with Kenya in early 2000 have grown substantially in terms of the amount invested. Such countries include Morocco, whose total value is USD 26.65 billion, Peru with an overall net worth of over USD 6.1 billion and Turkey, valued at more than USD 16 billion. Kenya, on the other hand, has a total value of USD 275.3 million [46]. The Kenyan case shows low growth in the sector and concern to the country, investors and other stakeholders. In addition, it reflects lack of understanding of the market by the investors or the fund managers are not doing enough to woo investors [1]. The dismal performance also leads to loss of confidence and erosion of investor's wealth in the unit trust [28].

On the relationship of fund size and performance of unit trusts, studies have shown mixed results. There is no clear documentation in the studies on a particular link between the performance of unit trust funds and fund size. Studies carried out in Kenya have not extensively addressed the connection amongst performance of unit trusts funds and the fund size. Discrepancies in findings on the same subject, in consequence, stirred the present study. The purpose of this study was to explore the effect of fund size on performance of unit trust funds using panel data for thirteen years and, also investigated the moderation effect of inflation on the relationship between fund size and performance of unit trusts funds in Kenya.

\subsection{Conceptual Frame Work}

The framework defines the researcher's conceptualization and interactions concerning the study variables. The conceptual framework graphical representation for this study is as in Figure 1

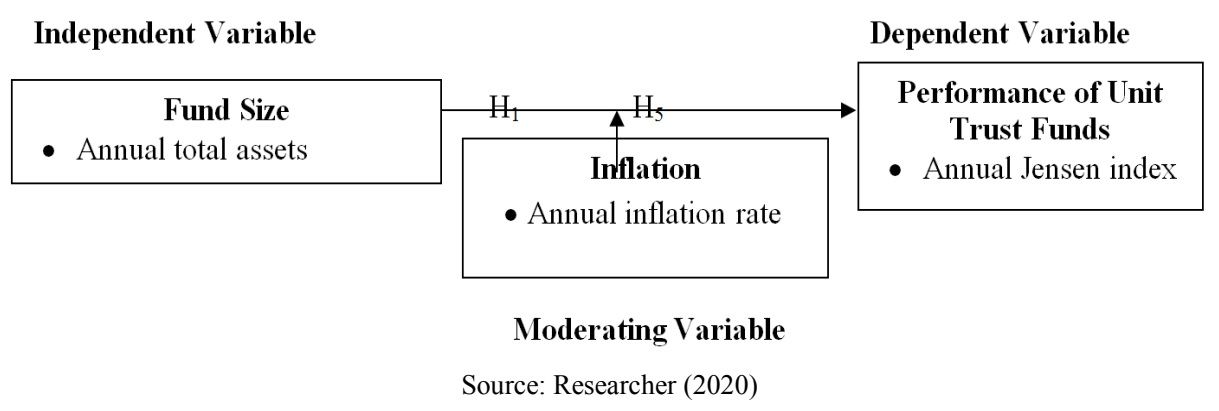

Figure 1 Conceptual Framework.

\section{Research Methodology}

\subsection{Research Philosophy and Design}

This research considers positivism philosophy to be the most appropriate because the study looks at the connection between fund characteristic and performance of unit trusts funds in Kenya. The event and environment of interest are objective, independent, and external of the researcher [6]. Subjective interpretations of results based on numbers have the minimal possibility [7]. Non-experimental explanatory research design was adopted to analyse the effect of fund size on the performance of unit trust funds in Kenya. Explanatory research establishes a causal association amongst variables [40]. Explanatory design is ideal where a study is endeavoring to clarify how phenomena function by finding the fundamental elements that bring change and in which case there is no manipulation of the independent variable [23]. Non-experimental design is an orderly practical enquiry where there is no express authority over the explanatory variables by investigators since symptoms happened in the past [23].

\subsection{Empirical Model}

Analysis of the effects of fund size on the performance of unit trust funds employed a panel regression model since the data had both cross-sectional and time-series dimensions as put forward by Greene (2008). The empirical model used in the study is as below:

for equity fund, money market fund, bond fund and balanced fund respectfully.

$$
\text { Fund Performance }=\beta_{0}+\beta_{2} \mathrm{FS}_{\mathrm{it}}+\mu_{i}+u_{i t}
$$




$$
\begin{aligned}
& \text { Fund Performance }=\beta_{0}+\beta_{2} \mathrm{FS}_{\mathrm{it}}+\mu_{i}+u_{i t} \\
& \text { Fund Performance }=\beta_{0}+\beta_{2} \mathrm{FS}_{\mathrm{it}}+\mu_{i}+u_{i t} \\
& \text { Fund Performance }=\beta_{0}+\beta_{2} \mathrm{FS}_{\mathrm{it}}+\mu_{i}+u_{i t}
\end{aligned}
$$

Where,

Fund Performance is the performance of each unit trust fund measured by Jensen Alpha model.

FS is the size of the unit trust fund.

$\mathrm{OE}$ is the unit trust fund operating expense.

SR is unit trust fund systematic risk (measured with Beta).

USR is unit trust fund Unsystematic risk

$\beta_{0}$ is the constant term

$\beta_{1} \ldots \ldots \beta_{5}$ represents coefficients of the explanatory variables

$\mathrm{i}=$ represents firms (cross-sectional dimension) ranging from 1 to 20

$\mathrm{t}=$ represents years (time series dimension) ranging from 2005 to 2017

$\mu_{i}=$ is Individual fund effect

$u_{i t}=$ Is idiosyncratic error term

\subsection{Moderating Effect of Inflation on the Relationship Between Fund Size and Performance of Unit Trust Funds in Kenya}

The Whisman and McClelland test for the moderation effect of inflation on the relationship between fund characteristics and performance of unit trusts funds in Kenya was adopted in this research [42]. The model proposes two main stages. First, inflation in a particular year is introduced in model $2 \mathrm{a}$ to $2 \mathrm{~d}$ as a variable as shown in equation $3 \mathrm{a}$ to $3 \mathrm{~d}$ below:

$$
\begin{aligned}
& \text { Fund Performance }=\beta_{0}+\beta_{2} \mathrm{FS}_{\mathrm{it}}+\beta_{5} 1 \mathrm{nIR}_{\mathrm{t}}+\mu_{i}+u_{i t}(5) \\
& \text { Fund Performance }=\beta_{0}+\beta_{2} \mathrm{FS}_{\mathrm{it}}+\beta_{5} 1 \mathrm{nIR}_{\mathrm{t}}+\mu_{i}+u_{i t}(6) \\
& \text { Fund Performance }=\beta_{0}+\beta_{2} \mathrm{FS}_{\mathrm{it}}+\beta_{5} 1 \mathrm{nIR}_{\mathrm{t}}+\mu_{i}+u_{i t}(7) \\
& \text { Fund Performance }=\beta_{0}+\beta_{2} \mathrm{FS}_{\mathrm{it}}+\beta_{5} 1 \mathrm{nIR}_{\mathrm{t}}+\mu_{i}+u_{i t}(8)
\end{aligned}
$$

Where $\mathrm{IR}_{\mathrm{t}}$ in the inflation rate in year $\mathrm{t}$.

Secondly, inflation is introduced as a moderator as shown in equation $3.8 \mathrm{a}$ to $3.8 \mathrm{~d}$ below:

$$
\begin{aligned}
& \text { Fund Performance }=\beta_{0}+\beta_{2} \mathrm{FS}_{\mathrm{it}}+\beta_{5} 1 \mathrm{nIR}_{\mathrm{t}}+\beta_{7}\left[F S_{i t} * \operatorname{InIR}_{\mathrm{t}}\right]+\mu_{i}+u_{i t} \\
& \text { Fund Performance }=\beta_{0}+\beta_{2} \mathrm{FS}_{\mathrm{it}}+\beta_{5} 1 \mathrm{nIR}_{\mathrm{t}}+\beta_{7}\left[F S_{i t} * \operatorname{InIR}_{\mathrm{t}}\right]+\mu_{i}+u_{i t} \\
& \text { Fund Performance }=\beta_{0}+\beta_{2} \mathrm{FS}_{\mathrm{it}}+\beta_{5} \operatorname{lnIR}_{\mathrm{t}}+\beta_{7}\left[F S_{i t} * \operatorname{InIR}_{\mathrm{t}}\right]+\mu_{i}+u_{i t} \\
& \text { Fund Performance }=\beta_{0}+\beta_{2} \mathrm{FS}_{\mathrm{it}}+\beta_{5} \operatorname{lnIR}_{\mathrm{t}}+\beta_{7}\left[F S_{i t} * \operatorname{InIR}_{\mathrm{t}}\right]+\mu_{i}+u_{i t}
\end{aligned}
$$

\subsection{Target Population and Data Collection}

The target population for this study was the 16 unit trusts firms in Kenya. These are the unit trust firms that are registered by CMA by this period and data was available. Data was collected using data extraction tool.

\section{Research Findings and Discussion}

Table 1. Descriptive Statistics.

\begin{tabular}{llllll}
\hline Fund & Variables & Mean & Std. Dev. & Minimum & Maximum \\
\hline \multirow{3}{*}{ Equity } & performance & -15.9348 & 4.576758 & -22.05 & -4.28 \\
& Fund Size & 8.20101 & 0.92488 & 5.01 & 9.79 \\
& Inflation Rate & 8.160109 & 3.233511 & 3.971667 & 16.23083 \\
Money & performance & -23.69112 & 11.79204 & -39.12 & 2.69 \\
market & Fund Size & 8.911495 & 0.6549662 & 6.52 & 10.16 \\
& Inflation Rate & 8.271214 & 3.293276 & 3.971667 & 16.23083 \\
& performance & -19.63447 & 4.804927 & -27.1 & -6.29 \\
& Fund Size & 7.652941 & 0.6777393 & 4.6 & 8.69 \\
& Inflation Rate & 8.091342 & 3.066169 & 3.971667 & 16.23083 \\
Balanced & performance & -10.21065 & 10.98119 & -37.92000 & -1.229000 \\
& Fund Size & 8.171414 & 0.7301426 & 5.7 & 9.3 \\
& Inflation Rate & 8.115689 & 3.124007 & 3.971667 & 16.23083 \\
\hline
\end{tabular}

Source: Study data (2020)

As indicated in Table 1, the mean performance of equity fund is -15.93475 below what is predicted by CAPM with a standard deviation of 4.576758 and minimum and maximum values of -22.05000 and -4.280000 , respectively. The standard deviation indicates that the data is highly variable as depicted by minimum and maximum values since it includes both small and large unit trust funds over the period. The negative value of the Jensen alpha indicates that equity funds, on average, underperform the market. The negative values for minimum and maximum indicate that all equity funds were underperforming the market in the period of study. Table 1 further indicates that each unit trust firm operates an average equity fund of 8.201010 . The fund size has a standard deviation of 0.924880 , a minimum value of 
5.010000, and a maximum of 9.790000 , which explains the high variation.

On the money market fund, Table 1 shows the mean performance as -23.69112 below what is predicted by CAPM. The standard deviation is 11.79204 , which shows data to be highly variable as depicted by minimum and maximum values of -39.12000 and 2.690000, respectively. The negative value of the Jensen alpha indicates that the money market fund, on average, is underperforming the market. The positive value indicates that some of the funds were over performing the market in the period of study. On fund size, Table 1 further indicates, on average, the firm size in the money market fund to be 8.911495 . The firm size has a standard deviation of 0.654966 , which means high variation, as illustrated by the minimum and maximum values of 6.520000 and 10.16000 respectfully.

Furthermore, the summary statistics in Table 1 indicate that, on average, during the period of analysis, the rate of inflation was 8.271214 per cent. The standard deviation was 3.293276 per cent, while the minimum and maximum values were 3.971667 and 16.23083 per cent, respectively. Therefore, during the period of analysis, the funds experienced mild to rapid levels of inflation. This situation is in harmony with the economic cycles during the study period. Further, guaranteeing the representative nature of data.

Also, Table 1 shows a mean performance of -19.63447 below what is predicted by CAPM on the bond fund. The standard deviation is 4.804927 showing that the performance is highly variable with minimum and maximum values of 27.10000 and -6.290000 , respectively. The negative value of the Jensen alpha indicates that the bond fund, on average, underperforms the market. The negative values for minimum and maximum indicate that all bond funds were underperforming the market in the period of study. The average amount of operating expense, as shown in Table 1, is 6.21221 for any of the bond funds. The fund size standard deviation is 0.677739 , with minimum values of 4.600000 and a maximum of 8.690000 , which shows the small funds and the large funds over the study period. Furthermore, the summary statistics in Table 1 suggest that, on average, during the period of analysis, the rate of inflation was 8.091342 per cent. The standard deviation was 3.066169 per cent, while the minimum and maximum values were 3.971667 and 16.23083 per cent, respectively. Therefore, during the period of analysis, the funds experienced mild to rapid levels of inflation. This scenario is in harmony with the economic cycles during the study period. Further, guaranteeing the representative nature of data.

The balanced fund, on the other hand, as depicted by Table 1 , has a mean performance of -10.21065 below what is predicted by CAPM. The minimum and maximum values are -37.92000 and -1.229000 , respectively. The negative value of the Jensen alpha indicates that the balanced fund has, on average, been underperforming the market. The negative values for minimum and maximum show that all balanced funds were underperforming the market in the period of study. The standard deviation of 10.98119 indicates a high variation in the performance of balanced funds within the period of study. On fund size, Table 1 further indicates, on average, the fund size of the balanced fund to be 8.171414. The fund size has a standard deviation of 0.730143 , with minimum values of 5.700000 and a maximum of 9.300000 . The standard deviation is highly variable over the period based on the size of the fund.

On the inflation rate, the summary statistics in Table 1 indicate that, on average, during the period of analysis, the inflation rate was 8.115689 per cent. The standard deviation was 3.124007 per cent, while the minimum and maximum values were 3.971667 and 16.23083 per cent, respectively. Therefore, during the period of analysis, the funds experienced mild to rapid levels of inflation. This inflation rate is in harmony with the economic cycles during the study period. Further, guaranteeing the representative nature of data.

\subsection{Hypothesis Testing}

This section presents the study findings thematically based on the study objectives. It shows the effect of operating expenses, fund size, systematic risk, and unsystematic risk on fund performance in Kenya. The model results were interpreted and discussed at a 95\% significance level $(\alpha=0.05)$.

Table 2. Effect of fund size on fund performance.

\begin{tabular}{llllll}
\hline Fund & Variable & Coefficient & Std. Error & t-Statistic & Prob. \\
\hline \multirow{2}{*}{ Equity } & Constant & $-1.41 \mathrm{E}+16$ & $4.26 \mathrm{E}+16$ & -0.330191 & 0.7421 \\
& Fund size & $2.51 \mathrm{E}+08$ & 25129369 & 10.00694 & 0.0000 \\
Money & Constant & 51851601 & 14981681 & 3.461000 & 0.0008 \\
market & Fund size & 0.085234 & 0.004061 & 20.98723 & 0.0000 \\
\multirow{3}{*}{ Bond } & Constant & 5020687. & 4061819. & 1.236069 & 0.2208 \\
& Fund size & 0.035612 & 0.010773 & 3.305717 & 0.0015 \\
\multirow{2}{*}{ Balanced } & Constant & -3534459. & 20990778 & -0.168382 & 0.8667 \\
& Fund size & 0.025146 & 0.019091 & 1.317167 & 0.0191 \\
\hline
\end{tabular}

Source: Study Data (2020)

The findings in Table 2 indicate that the p-values are less than the significance level of 0.05 . Fund size has a significant positive connection with performance in all funds.

\subsection{Fund Size and Performance of Unit Trust Funds}

In light of the objective, the study sought to establish the effect of fund size on the performance of unit trust funds in Kenya. Testing done on the null hypothesis $\left(\mathrm{H}_{01}\right)$ is that; fund size has no significant effect on the performance of unit trust funds in Kenya. Table 2 shows that the coefficient of fund size in the equity fund is $2.51 \mathrm{E}+08$, with corresponding $\mathrm{p}$-values of 0.0000 and t-statistic of 10.00694 . The p-value is less than 0.05 , and hence the null hypothesis is rejected, meaning that fund size affects the performance of equity fund. In the money market fund, the coefficient is 0.085234 , with a p-value of 0.0000 and a t-statistic of 20.98723. The p-value is less than 0.05 , and hence the null hypothesis is rejected. Fund size, therefore, affects the performance of money market funds.

On bond fund, the coefficient is 0.035612 , with a corresponding value of $\mathrm{p}$-value of 0.0 .0015 and $\mathrm{t}$-statistic of 
3.305717. The p-value is less than 0.05 , hence rejecting the null hypothesis. Fund size, therefore, affects the performance of the bond fund. For the balanced fund, the coefficient is 0.025146 , with a p-value of 0.0191 and a t-statistic of 1.317167. The p-value is less than 0.05 , and hence the null hypothesis is rejected, meaning that fund size affects the performance of balanced funds in Kenya. The coefficients of fund size in all funds are positive, meaning that fund size and performance have a positive relationship in that an increase in fund size increases the performance of unit trust fund in Kenya. These findings do not agree with the results by [34], [29], 41, and [33], who observed no effect of fund size on the performance of unit trust funds. Ainulashikin and Andrew saw a significantly negative effect [4] while Samira and Slaheddine; and Maina found a significant positive effect of fund size and performance of unit trust funds, which agree with the findings in this study [39]; [26].

\subsection{Moderating Effect of Inflation on the Relationship Between Fund Size and Performance of Unit Trust Funds}

The testing of the second hypothesis was tested through the estimation of model $2 \mathrm{a}-2 \mathrm{~d}$ and $3 \mathrm{a}-3 \mathrm{~d}$. Table 3 below reports model $2 \mathrm{a}-2 \mathrm{~d}$ estimates, and Table 4 illustrates the estimates of model $3 \mathrm{a}-3 \mathrm{~d}$. The results in Table 3 were interpreted simultaneously with those of Table 4.
Table 3. Inflation as an independent variable.

\begin{tabular}{llllll}
\hline Fund & Variable & Coefficient & $\begin{array}{l}\text { Standard } \\
\text { Errors }\end{array}$ & t-Statistic & P-value \\
\hline \multirow{2}{*}{ Equity } & Constant & $-7.26 \mathrm{E}+16$ & $6.16 \mathrm{E}+16$ & -1.178493 & 0.2416 \\
& Fund size & $2.50 \mathrm{E}+08$ & 23368196 & 10.70613 & 0.0000 \\
& Inflation rate & $6.74 \mathrm{E}+15$ & $5.73 \mathrm{E}+15$ & 1.176464 & 0.2424 \\
\multirow{2}{*}{ Money } & Constant & 34809098 & 23445998 & 1.484650 & 0.1408 \\
market & Fund size & 0.084472 & 0.003862 & 21.87034 & 0.0000 \\
& Inflation rate & -580205.5 & 1993357. & -0.291070 & 0.7716 \\
\multirow{2}{*}{ Bond } & Constant & 7932359. & 3388655. & 2.340858 & 0.0218 \\
& Fund size & 0.035253 & 0.008265 & 4.265348 & 0.0001 \\
\multirow{2}{*}{ Balanc } & Inflation rate & -473258.3 & 179692.3 & -2.633715 & 0.1002 \\
ed & Constant & 63626836 & 26668174 & 2.385872 & 0.0191 \\
& Fund size & 0.017187 & 0.018059 & 0.951714 & 0.0343 \\
\hline
\end{tabular}

Source: Study data (2020)

Table 3 above indicates that the coefficient of inflation, which is of interest under model $2 \mathrm{a}-2 \mathrm{~d}$ in the equity fund, is $6.74 \mathrm{E}+15$ with a corresponding $p$-value of 0.2424 , which is higher than the level of significance of 0.05 hence insignificant. In the money

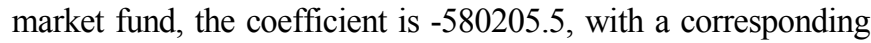
p-value of 0.7716 . The $p$-value is greater than 0.05 hence insignificant. The bond fund has a coefficient of -473258.3 , with a p-value of 0.1002 . The $p$-value is greater than 0.05 ; hence the coefficient is insignificant. On the other hand, the balanced fund has a coefficient of -6778164 , with a p-value of 0.1603 . The $p$ value is greater than 0.05 ; hence the coefficient is insignificant.

Table 4. Inflation as a Moderator on the relationship between fund size and performance.

\begin{tabular}{|c|c|c|c|c|c|}
\hline Fund & Variable & Coefficient & Standard Errors & t-Statistic & P-value \\
\hline \multirow{4}{*}{ Equity } & Constant & $-1.59 \mathrm{E}+16$ & $1.14 \mathrm{E}+17$ & -0.140278 & 0.8888 \\
\hline & Fund size & $2.76 \mathrm{E}+08$ & 79163504 & 3.487174 & 0.0008 \\
\hline & Inflation rate & $-5.13 E+13$ & $1.28 \mathrm{E}+16$ & -0.004001 & 0.0368 \\
\hline & Fund size $*$ Inflation rate & -3927205. & 10124781 & -0.387881 & 0.0340 \\
\hline \multirow{3}{*}{ Money market } & Constant & 30262369 & 42043321 & 0.719790 & 0.4734 \\
\hline & Fund size & 0.045882 & 0.021592 & 2.124988 & 0.0362 \\
\hline & Inflation rate & 243866.9 & 5002663. & 0.048747 & 0.0162 \\
\hline \multirow{4}{*}{ Bond } & Constant & -3512189 & 7365573. & -0.476839 & 0.6349 \\
\hline & Fund size & 0.035443 & 0.023182 & 1.528931 & 0.0130 \\
\hline & Inflation rate & 875316.5 & 796057.4 & 1.099564 & 0.0275 \\
\hline & Fund size * Inflation rate & $7.11 \mathrm{E}-05$ & 0.002529 & 0.028098 & 0.0197 \\
\hline \multirow{3}{*}{ Balanced } & Constant & -32501217 & 61125236 & -0.531715 & 0.5963 \\
\hline & Fund size & 0.144451 & 0.047497 & 3.041281 & 0.0031 \\
\hline & Inflation rate & 5154691. & 7625258 & 0.676002 & 0.0500 \\
\hline
\end{tabular}

Source: Study data (2020)

Table 4 above illustrates the introduction of inflation as a moderator. The coefficient of interest is that of the interaction term. The coefficients of the interaction term for fund size in equity fund is significant. In Table 3 , the coefficient of inflation for the equity fund is insignificant. The null hypothesis that inflation has no moderating effect in the relationship between fund size and the performance of unit trust funds in Kenya is rejected at the significance levels of 0.05 for the equity, money market,bond and balanced funds. For this reason, inflation has a moderating effect on the relationship between fund size and performance of all funds in Kenya.

These findings are consistent with lemantile who observed a negative effect on performance [24] and contradicts Mohammadreza and Esmaeel who observed a positive effect of inflation on performance [31].

\section{Summary, Conclusion and Recommendations}

\subsection{Summary}

The background presented in the study culminated to the statement of the problem. The study formulated research objectives to address the Research problem. A conceptual 
framework was developed to show the relationship between the variables. The research methodology of the study is given and explanation for choosing it. Non-experimental explanatory research design and a census of sixteen unit trust firms were taken. Panel data for the period 2005 to 2017 was used for analysis. The study found performance averages on all funds to be negative, indicating their performance to be below that which is predicted by CAPM. Additionally, their standard deviations were higher than the mean, an indication that the data was highly spread.

The study sought to establish the effect of fund size on the performance of unit trust funds. The findings were that there is a significant positive relationship with performance in all funds. Therefore as the size of fund increases, performance increases. Further, the study sought to investigate the moderating effect of inflation on the relationship between fund size and the performance of unit trust funds. The study findings revealed that inflation significantly moderates the relationship between fund size and the performance of unit trust funds.

\subsection{Conclusion}

The study makes several conclusions based on the empirical findings in relation to the study objectives and hypotheses. Most unit trust funds' performance is below the CAPM predicted performance. In light of the test of $\mathrm{H}_{01}$, the study found out that fund size has a positive and significant effect on the performance of all unit trust funds. This finding is supported by several empirical studies but also contradicts other studies. Hence the study concludes that increased fund size increases the amounts of investments and helps funds enjoy the economies of scale, leading to improved performance.

Finally, the result of $\mathrm{H}_{02}$, points out that inflation has a moderating effect on the relationship between fund characteristics and performance of unit trust funds. Hence the study concludes that inflation moderates the relationship between fund size and performance of unit trust funds.

\subsection{Recommendations}

In light of the findings of the study and conclusions thereof, some recommendations to policy and practice are noteworthy. Firstly, the management of unit trust funds ought to be more careful in handling and better usage of resources to improve the performance of the unit trusts. Secondly, the management of unit trust funds ought to work closely with the regulator (CMA) to create a supportive environment for the unit trust firms to increase their fund size and managerial capacity. There ought to be constant monitoring and supervision, designing an in-service course in management of unit trust funds to improve administrative ability, and offering technical support. The academicians can use the contribution of fund size on performance to identify the knowledge gaps and pursue further research in the area. Finally, the fiscal and monetary policy implementers should seek to maintain desirable levels of inflation based on the performance of the economy.

\section{References}

[1] Batra G., Laxmi V. \& Gupta A. (2012). Mining the Investor's Perceptions About Different Investment Options Using Clustering Analysis. International Journal on Computer Science and Engineering, 4 (9), 1513.

[2] Berk J. B. \& Green R. C. (2004). Mutual fund flows and performance in rational markets. Journal of political economy, $112(6), 1269-1295$.

[3] Bhatti M. I. (2009). Human Capital Needs in Islamic Banking and Finance Industry. Paper presented at the Islamic Banking and Finance Symposium, Melbourne, Australia on 6th July 2009.

[4] Ainulashikin M. \& Andrew W. (2015). Comparative performance-related fund flows for Malaysian Islamic and conventional equity funds, International Journal of Islamic and Middle Eastern Finance and Management, 8 (3), 380-394,

[5] Brennan M. \& Hughes J. (1991). The individual investor. Journal of Financial Services Research 18 (1): 59-74.

[6] Bryman A. \& Bell E. (2003). Business Research Methods. Oxford, Oxford University Press.

[7] Bryman A. \& Bell E. (2011). Business research methods (3rd Ed.), Oxford: Oxford University Press.

[8] Capital Market Authority (2017). The Capital Markets Soundness Report 2016, Nairobi

[9] Carhart M. (1997). On Persistence in Mutual Fund Performance, Journal of Finance, 52 (1), 57-82.

[10] Chen J., Hong H., Huang M. \& Kubick J. D. (2004). Does Fund Size Erode Mutual Fund Performance? The Role of Liquidity and Organization. American Economic Review, 44, 1276-1302.

[11] Cremers K. M. \& Petajisto A. (2009). How active is your fund manager? A new measure that predicts performance. The Review of Financial Studies, 22 (9), 3329-3365.

[12] Dahlquist M., Engström S. \& Söderlind P. (2000). Performance and Characteristics of Swedish Mutual Funds. Journal of Financial and Quantitative Analysis, 35 (3), 409423.

[13] Edelen R., Evans R. \& Kadlec G. (2007). Scale effects in mutual fund performance: The role of trading costs.

[14] Fredrik K., Han-Suck S. \& Mats W. (2015). Determinants of mutual fund flows, Managerial Finance, 41 (1), 10-25.

[15] Gitagia F. (2012). Fundamentals That Predict Mutual Fund Performance: A case of fund managers in Kenya, Master Thesis on MBA Accounting and Finance, Kenyatta University.

[16] Goetzmann W. N. (2000). An Introduction to Investment Theory ( $5^{\text {th }}$ ed.). Yale: Ibbotson Associates.

[17] Goetzmann W. N., Ravid S. A. \& Sverdlove R. (2012). The pricing of Soft and Hard Information: Economic Lessons from Screenplay Sales. Journal of Cultural Economics, 1-37.

[18] Greene W. H. (2008). Econometric Analysis (6 ${ }^{\text {th }}$ ed). Upper Saddle River, N. J.: Prentice Hall 
[19] Grinblatt M. \& Titman S. (1989). Mutual Fund Performance: An Analysis of Quarterly Portfolio Holdings. The Journal of Business, 62(3), 393-416.

[20] Halil K. (2015). A performance evaluation of Chinese mutual funds, International Journal of Emerging Markets, 10(4), 820836 .

[21] Investment Company Institute (2012). Investment Company Fact Book 2012, Investment Company Institute, Washington, $\mathrm{DC}$,

[22] Investment Company Institute (2018). Investment Company Fact Book 2018, a review of trends and activities in the Investment Company Industry; $58^{\text {th }}$ edition Ippolito R. A. (1989). Efficiency with costly information: A study of mutual fund Performance, 1965-1984. Quarterly Journal of Economics 104, 1-23.

[23] Kerlinger F. N. \& Lee H. B. (2000). Foundations of behavioural research (4th ed.). Fort Worth, TX: Harcourt.

[24] Lemantile, A. L. (2017). Effects of Macro-Economic Factors on the Financial Performance of Mutual Funds in Kenya (Doctoral dissertation, United States International UniversityAfrica).

[25] Maina F. G. \& Sakwa M. M. (2012). Understanding financial distress among listed firms in Nairobi stock exchange: A quantitative approach using the Z-score multi-discriminant financial analysis model. In Scientific Conference Proceedings.

[26] Maina R. W. (2013). The effect of portfolio characteristics on financial performance of unit trusts in Kenya. Unpublished MBA research project, school of business, University of Nairobi.

[27] Makori M. D. (2017). Short-Term Financing Decisions and Financial Performance of Non-Financial Firms Listed at The Nairobi Securities Exchange, Kenya. Doctoral Dissertation, Kenyatta University.

[28] Marangu K. (2015). Firm Characteristics and Share Returns of Secondary Equity Offers at Nairobi Securities Exchange, Kenya. PhD Thesis, Kenyatta University.

[29] Mbataru C. K. (2012). Factors Affecting the Performance of Unit Trust Funds in Kenya. Master Thesis on MBA Finance and Accounting, University of Nairobi.

[30] Mohamed A. B. (2016). Factors Affecting the Financial Performance of Investment Funds A Comparative Study: Islamic Versus Conventional Funds. Unpublished M.Sc Thesis in Business Administration, Mansoura University.

[31] Mohammadreza M. \& Esmaeel R. (2013). The Effect of Economic Factors on the Efficiency of Mutual Funds in Iran Seyedeh Javaneh Ahmadi Tulamy, Technical Journal of Engineering and Applied Sciences 3(15), 1707-1711.

[32] Ngugi R., Amanja D. \& Maina I. (2009). Capital market, financial deepening and economic growth in Kenya. Centre for the study of African economies Conference, 22-24.

[33] Norma M., Saad M., Shabri A., Majid, Salina K., Zarinah H., Rosylin M. Y. (2010). A comparative analysis of the performance of conventional and Islamic unit trust companies in Malaysia, International Journal of Managerial Finance, $6(1), 24-47$

[34] Ombongi P. N. (2014). Determinants of financial performance of unit trusts in Kenya. Unpublished MBA project, University of Nairobi.

[35] Plantier, C. (2015). Regulated funds, emerging markets, and financial stability. ICI Global Research Perspective, 2(1).

[36] Pollet J. \& Wilson M. (2008). How Does Size Affect Mutual Fund Behaviour. Journal of Finance, 63(6), 1-49.

[37] Reilly F. K. \& Brown K. C. (2011). Investment Analysis and Portfolio Management $\left(10^{\text {th }}\right.$ ed.). Mason: South Western Cengage Learning.

[38] Republic of Kenya (2007). Kenya vision 2030, Nairobi: Government Press Robson C. (2002). Real World Research: A Resource for Social Scientist and practioners, Research oxford Blackwell.

[39] Samira B. B. \& Slaheddine H. (2011). Predicting Tunisian mutual fund performance using dynamic panel data model. The Journal of Risk Finance, 12(3), 208-225.

[40] Saunders M., Lewis P. \& Thornhill A. (2009). Research methods for business Students. $5^{\text {th }}$ ed Italy: Prentice Hall.

[41] See Y. P. \& Jusoh R. (2012). Fund characteristics and fund performance: Evidence of Malaysian mutual funds. International Journal of Economics and Management Sciences, 1(9), 31-43.

[42] Whisman, M. A., \& Mc Clelland, G. H. (2005). Designing, Testing, and Interpreting Interactions and Moderator Effects in Family Research. Journal of Family Psychology, 19 (1), $111-120$

[43] Wilcox J. W. \& Fabozzi F. J. (2013). Financial Advice and Investment Decisions ( $1^{\text {st }}$ ed.). New York: Wiley.

[44] William J. T. (2010). Performance measurement of high yield bond mutual funds. Management Research Review, 33(6), 609-616,

[45] Wilson R. (2010). The Economics of Mutual Funds: An Islamic Approach.

[46] World Bank (2015). Mutual Funds in Developing Markets; Addressing Challenges to Growth. 1818 H Street NW, Washington DC 20433.

[47] Yan X. (2008). Liquidity, Investment Style and the relation between fund size and fund performance, journal of financial and quantitative analysis, 43, 741-768.

[48] Yin-Ching J. \& Hung M. W. (2003). Mutual fund attributes and performance, Financial Services Review, 12(2), 165-78.

[49] Praveen K., Das S. P. \& Uma R. (2013). Performance evaluation of socially responsible mutual funds using style analysis, Social Responsibility Journal, 9 (1), 109-123.

[50] Bonolo M. T., Beatrice D. S., \& John W. M. M. (2017). Performance evaluation of equity unit trusts in South Africa. Managerial Finance, 43(3), 379-40.

[51] Malhotra M., Thenmozhi M. \& Arunkumar C. (2013). Factors Influencing Abnormal Returns Around Bonus and Rights Issue Announcements. Journal of Applied Finance, 19(4), 41-60.

[52] Ali M. G. H. (2012). A Comparative Analysis of the Performance of the Investment Funds on the National Commercial Banks of Egypt. Unpublished M.Sc. thesis Faculty of Commerce, Mansoura University. 